\title{
APLIKASI INTELLIGENCE WEBSITE UNTUK PENUNJANG LAPORAN PAUD PADA HIMPAUDI KOTA TANGERANG
}

\author{
Dina Fitria Murad ${ }^{1}$ \\ Nia Kusniawati² \\ Agus Asyanto $^{3}$ \\ e-mail :dinafitriamurad@gmail.com
}

Diterima: 19 Juni 2013 / Disetujui: 23 Agustus 2013

\begin{abstract}
The development of technology has affected all the human life as well in education aspect. The computer device usage become usual to be applied in education, especially in managing student data for report making. Like any organization, HIMPAUDI Kota Tangerang strives to realize the computer application using to evaluating regular reports of PAUD, early childhood education institutions in each month. The report which written manually by paper media has created many obstacles in the process of recapitulation of the whole report by HIMPAUDI. Furthermore, the problem of the delaying PAUD report caused by the location of PAUD which spread across Tangerang. HIMPAUDI districts subdivision tasked to collect regular reports on each district and give it to HIMPAUDI. These activities take much time so the collection of regular monthly reports being late. With these problems, the authors conducted an analysis to find solutions to these problems using waterfall method by creating a HIMPAUDI website that can be used by PAUD to send their report easily. PAUD administrator easily access the website for report delivery in excel file format, that can be directly sent to HIMPAUDI website and automatically recapitulated in to graphical form which received by HIMPAUDI. In addition, the HIMPAUDI can choose parameters such graphs are shown by year, age, study groups, etc.. So the monitoring process of report distribution and recapitulation will automatically processed by the system with good performance, well integrated, reduces error rate, saving time and cost, and help HIMPAUDI to monitor the development of PAUD easily.
\end{abstract}

1. Dosen Jurusan Teknik Informatika, STMIK Raharja Jl. Jend Sudirman No. 40 Modern Cikokol-Tangerang Telp. 5529692

2. Mahasiswa Jurusan Sistem Informasi, STMIK Raharja

Jl. Jend Sudirman No. 40 Modern Cikokol-Tangerang Telp. 5529692

3. Mahasiswa Jurusan Sistem Informasi, STMIK Raharja

Jl. Jend Sudirman No. 40 Modern Cikokol-Tangerang Telp. 5529692 
Keywords : HIMPAUDI, report, PAUD, website, monitoring.

\begin{abstract}
ABSTRAKSI
Perkembangan teknologi yang semakin pesat telah mempengaruhi seluruh aspek kehidupan manusia termasuk juga dalam aspek pendidikan. Penggunaan perangkat komputer menjadi hal yang biasa diterapkan di dunia pendidikan terutama dalam mengelola data-data kesiswaan untuk pembuatan laporan. Seperti halnya organisasi HIMPAUDI Kota Tangerang yang berusaha mewujudkan penerapan penggunaan komputer dalam mengevaluasi laporan rutin dari lembaga pendidikan PAUD setiap bulannya. Laporan yang ditulis secara manual dengan media kertas telah menimbulkan banyak kendala dalam proses rekapitulasi laporan keseluruhan oleh HIMPAUDI. Selain itu, masalah keterlambatan laporan PAUD yang diakibatkan karena letak PAUD yang tersebar di seluruh penjuru Kota Tangerang. HIMPAUDI kecamatan bertugas untuk mengumpulkan laporan rutin di tiap kecamatan dan memberikannya kepada HIMPAUDI kota. Kegiatan ini memakan waktu yang cukup banyak sehingga pengumpulan laporan rutin perbulan menjadi terlambat. Dengan permasalahan ini, penulis melakukan analisa untuk memecahkan permasalahan yang terjadi menggunakan metode waterfall untuk merancang aplikasi berbasis website yang dapat digunakan PAUD dengan mudah. Pengurus PAUD dapat mengakses website HIMPAUDI, melakukan upload laporan dalam bentuk file excel dan dapat direkapitulasi secara otomatis oleh sistem ke dalam bentuk grafik. HIMPAUDI juga dapat dengan mudah memilih parameter-parameter grafik yang dapat dilihat berdasarkan tahun, umur, kelompok belajar, dan lain sebagainya. Dengan begitu proses pengawasan rekapitulasi laporan dapat diproses oleh sistem dengan kualitas pengolahan yang baik, mengurangi tingkat kesalahan, hemat waktu dan biaya, serta membantu kinerja HIMPAUDI menjadi lebih baik lagi.
\end{abstract}

Kata kunci : HIMPAUDI, laporan, PAUD, website, monitoring

\title{
PENDAHULUAN
}

Perkembangan teknologi yang pesat saat ini sangatlah berpengaruh dalam tiap aspek kehidupan bermasyarakat di era globalisasi, termasuk juga dalam dunia pendidikan. Lembaga pendidikan formal maupun non-formal sangat membutuhkan sistem kerja yang cepat dan akurat yang dapat menunjang kegiatan pendidikan setiap harinya. Masalah ketersediaan informasi yang tepat dan bebas dari kesalahan merupakan faktor yang sangat penting dalam menilai kualitas dari lembaga pendidikan tersebut. Selain itu, ketersediaan informasi yang baik telah menjadi suatu kebutuhan bagi pihak menejemen maupun lembaga di atas yang menaunginya, yang tersusun secara baik dan praktis dalam bentuk laporan. Dengan demikian, dibutuhkan sebuah sistem yang berbasiskan komputer untuk menunjang dan mengatasi permasalahan yang terjadi pada kegiatan tersebut. 
Penggunaan komputer dalam kehidupan sehari-hari telah menjadi hal yang biasa dan dapat diterapkan secara fleksibel dimana saja dan kapan saja. Sebagian besar masyarakat telah familiar dalam menggunakan komputer. Keandalan perangkat keras dan perangkat lunak serta didukung oleh sumber daya manusia (brainware) yang memadai akan menjadikan masalah ketersediaan informasi terkendali dengan sebuah sistem informasi. Sistem informasi yang mudah digunakan dan efektif digunakan secara hirarki akan menunjang kegiatan laporan dan dapat digunakan sebagai sistem penunjang keputusan bagi lembaga-lembaga yang menaungi lembaga pendidikan tersebut.

HIMPAUDI Kota Tangerang merupakan sebuah lembaga yang menaungi lembaga pendidikan PAUD yang ada di Kota Tangerang. HIMPAUDI Kota Tangerang terdiri dari beberapa HIMPAUDI Kecamatan yang bertugas di masingmasing kecamatan yang ada di Kota Tangerang. HIMPAUDI Kecamatan bertugas sebagai penerima laporan dari PAUD-PAUD terdaftaryang nantinya akan dikirimkan ke HIMPAUDI pusat. Laporan tersebut sangat bermanfaat bagi analisa dan faktor penunjang keputusan bagi perencanaan-perencanaan di masa yang akan datang. Selain itu, hasil analisa laporan tersebut juga dapat digunakan sebagai tingkat perkembangan kualitas hidup di kota Tangerang. Akan tetapi masih banyak ditemukan kendala dalam memproses laporan-laporan tersebut menjadi bentuk yang mudah dipahami. Laporan tersebut harus direkapitulasi terlebih dahulu agar dapat terlihat secara pasti bagaimana perkembangannya sehingga HIMPAUDI pusat dapat melakukan analisa hasil laporan dan merancang strategi dan pengambilan keputusan. Laporan yang masih ditulis manual dengan media kertas terkadang sulit dan membutuhkan waktu yang lama untuk direkapitulasi, terlebih lagi untuk semua laporan PAUD di seluruh kecamatan di Kota Tangerang yang jumlahnya ratusan tiap bulannya. Selain itu, kendala ruang penyimpanan berkas laporan PAUD tiap bulannya terkadang menimbulkan masalah. Proses rekapitulasi yang sering terlambat menyebabkan laporan-laporan yang belum sempat diproses tersebut ditumpuk dan terkadang terlupakan, bahkan banyak laporan yang sudah rusak dan menghabiskan banyak tempat penyimpanan. Untuk itu, dibutuhkan sistem yang dapat menampung laporan-laporan tersebut secara apik dan menarik, serta praktis dan efektif dalam memperoleh hasil analisa laporan tersebut.

\section{PERMASALAHAN}

Berdasarkan latar belakang di atas, maka perumusan masalah dalam penelitian ini adalah sebagai berikut:

1. Bagaimana sistem pelaporan di HIMPAUDI saat ini? 
2. Apakah dibutuhkan sistem informasi berbasis komputer dalam kegiatan laporan pada HIMPAUDI Kota Tangerang?

3. Bagaimana merancang sistem laporan yang berguna untuk memonitor seluruh laporan PAUD di Kota Tangerang?

4. Bagaimana membangun aplikasi yang mempermudah setiap PAUD mengirimkan laporan ke HIMPAUDI?

5. Bagaimana membangun aplikasi sistem laporan yang berbasis teknologi Business Intelligence yang tepat digunakan dalam kegiatan analisa laporan HIMPAUDI Kota Tangerang?

\section{LITERATURE REVIEW}

1. Menurut Henderi dkk (2011) pada jurnal CCIT No.5 Vol.1, September 2011 yang berjudul "Dashboarding Information System for the Education Sector: Application and Methodologies”, mengemukakan bahwa Sektor pendidikan di Indonesia saat ini tidak lepas dari peran serta teknologi informasi. Bukan hanya dalam kegiatan belajar mengajar saja, tetapi juga dalam mengelola data sehingga dihasilkan sebuah laporan (report) kepada pimpinan organisasi pendidikan tersebut dibutuhkan sistem pengelolaan data yang cepat dan dengan tampilan yang baik dan update. Sehingga peneliti melakukan penelitian berupa perancangan sebuah tampilan laporan yang sebelumnya dalam bentuk tabel yang sulit dimengerti menjadi grafik dan dashboard yang handal, sehingga pimpinan organisasi pendidikan dapat dengan mudah melihat perkembangan kualitas dan mutu di sekitar area organisasi dengan melihat key performance indicators (KPI)[1].

2. Menurut Bing Tan,dkk (2010) pada jurnal Cybernetics and System: An International Journal Vol.33, November 2010 yang berjudul "Web Information Monitoring for Competitive Intelligence” mengemukakan bahwa web merupakan salah satu media yang paling penting dalam penyebaran informasi saat ini, dan digunakan di banyak bidang khususnya perusahaan sebagai sumber competitive intelligence (CI). Penelitian ini mengusulkan sebuah sistem monitoring web, WebMon, untuk membantu pengguna memantau halaman web ditentukan untuk perubahan terbaru dan update informasi. Empat fungsi pemantauan termasuk pemantauan tanggal, monitoring kata kunci, monitoring link dan pemantauan porsi yang didukung oleh sistem. Oleh karena itu, kinerja dari fungsi pengawasan juga dapat dievaluasi [2].

3. Menurut Tubagus Ahmad Harja Kusuma (2012) pada penelitian yang berjudul “Dashboard Monitoring Sistem Transaksi Penjualan MKIOS dalam 
Mendukung Sistem Klasifikasi Reward pada PT. Sastra Indah Megahmas", mengemukakan bahwa terdapat beberapa kelemahan dari sistem lama yaitu mengenai distribusi data transaksi pulsa di setiap daerah. Untuk itu dibutuhkan sebuah sistem informasi yang tepat untuk menangani masalah tersebut dangan tampilan yang mudah dimengerti dan menunjang untuk pengambilan keputusan. Sistem yang diusulkan ini menggunakan teknologi Business Intelligence yang diterapkan dalam tampilan dashboard monitoring. Selain itu, kemudahan yang didapat adalah transaksi-transaksi yang terdapat di tiap daerah dapat dengan mudah di-upload dalam bentuk Microsoft Excel, kemudian langsung tereksport dalam bentuk dashboard. Dengan begitu, akan memudahkan manajer dalam monitoring dan pengambilan keputusan, serta meminimalkan biaya dan meningkatkan efisiensi dan efektifitas kerja [3].

4. Menurut Mahesh S dan John H (2001) pada jurnal . Journal of Electronic Commerce Research, Vol. 2, No. 1, 2001 yang berjudul "An Automated Executive and Managerial Performance Monitoring, Measurement and Reporting System ” mengemukakan bahwa Konsep pemanfaatan aplikasi dan tools untuk memonitor, mengukur, dan melaporkan penyimpangan pada KPI (Key Performance Indicator) dengan menggunakan aplikasi IVAAN ${ }^{\mathrm{TM}}$. Pihak eksekutif dapat langsung memantau KPI dengan kualitas informasi yang update dan bebas dari human error karena sistem pengolahan data tidak memerlukan intervensi dari manusia [4].

5. Menurut Sudi Hartati (2009) pada penelitian yang berjudul "Perancangan Sistem Penyajian Laporan Realisasi Anggaran pada Badan Pusat Statistik Kota Tangerang” mengemukakan bahwa Ditemukan bahwa proses penyimpanan data sudah menggunakan sistem komputer, namun masih sering juga terjadi penumpukan data. Dengan penumpukan data tersebut menyebabkan kesulitan dalam pemrosesan data dan penyajian dalam bentuk laporan yang akurat dan tepat waktu. Untuk itu dibuatlah sistem penyajian laporan yang diharapkan dapat membantu dalam pengolahan laporan secara efektif, efisien, dan akurat. Selain itu diharapkan pula dapat mempermudah user, menghemat waktu dan biaya. Aplikasi ini dibuat denagn bahasa pemrograman PHP dan MySQL sebagai database-nya, serta dinilai cukup baik dalam pengaplikasiannya pada Badan Pusat Statistik Kota Tangerang [5].

\section{PEMECAH MASALAH}




\section{Teori Pendukung}

\section{a. Intelligence Website}

Berdasarkan permasalahan tersebut, penulis mengusulkan sebuah rancangan aplikasi berbasis website yang disebut intelligence website. Berikut merupakan definisi intelligence dan website yang dikemukakan oleh beberapa ahli:

Menurut Vicki L. Sauter, "intelligence is the communication facility serving the conduct of a business (in the broad sense) may be referred to as an intelligence system. The notion of intelligence is also defined as "the ability to apprehend the interrelationships of presented facts in such a way as to guide action towards a desired goal. In other words, expert systems (or intelligence) technology became a modeling support function, albeit an important one, for decision support systems [6]."

Penjelasan tersebut dapat ditafsirkan menjadi, intelligence adalah komunikasi yang membantu pelaksanaan bisnis yang dapat diasumsikan sebagai intelligence system. Kecerdasan juga didefinisikan sebagai kemampuan untuk menangkap hubungan timbal balik fakta yang disajikan sedemikian rupa untuk membimbing tindakan ke arah tujuan yang diinginkan. Dengan kata lain, sistem pakar (atau kecerdasan) teknologi menjadi fungsi pendukung pemodelan, yang merupakan sesuatu yang penting untuk sistem pendukung keputusan.

Menurut Leo D. Carl dalam bukunya yang berjudul International Dictionary of Intelligence mendefinisikan intelligence sebagai "the product resulting from the collecting and processing of information concerning actual and potential situations and conditions relating to domestic and foreign activities and to domestic and foreign or US and enemy-held areas [7]."

Dapat ditafsirkan sebagai produk yang dihasilkan dari pengumpulan dan pengolahan informasi mengenai situasi dan kondisi aktual dan potensial yang berhubungan dengan kegiatan domestik dan asing atau AS dan wilayah yang dikuasai musuh.

Web adalah sebuah sistem dengan informasi yang disajikan dalam bentuk teks, gambar, suara, dan lainnya yang tersimpan dalam sebuah server web internet yang disajikan dalam bentuk hypertext. Informasi web pada umumnya ditulis dalam format HTML. Interaksi web dibagi dalam 3 langkah yaitu permintaan, pemrosesan, dan jawaban [8]. Web dalam ilmu komputer/internet khususnya adalah jaringan luas yang mencakup seluruh dunia [9].

Berdasarkan definisi intelligence dan definisi website menurut para ahli tersebut, penulis dapat menyimpulkan bahwa pengertian dari intelligence website adalah sebuah aplikasi berbasis website yang digunakan untuk menangani masalah- 
masalah bisnis dalam pemrosesan data yang berupa fakta-fakta menjadi informasi yang digunakan dalam membantu proses penunjang pengambilan keputusan.

\section{b. Laporan}

Salah satu poin penting dalam penelitian ini, adalah bagaimana memproses dan mengintegrasikan sebuah laporan. Berikut ini merupakan pengertian laporan menurut beberapa ahli:

Laporan adalah bentuk penyajian fakta tentang suatu keadaan atau kegiatan. Fakta yang disajikan berkenaan dengan tanggung jawab yang ditugaskan pada pelapor. [10].

Menurut Rakesh TK, "Reporting Solution is to deliver and implement a consistent, personalized information delivery system that includes performance data (key performance indicators) which are relevant, accurate and transparent for use by regional management and executives to enable decision making each month [11]."

Dapat ditafsirkan sebagai, laporan merupakan kumpulan data yang didalamnya dibentuk berdasarkan KPI (key performance indicators) yang relevan, akurat dan transparan untuk digunakan oleh pihak manajemen atau eksekutif dalam pengambilan keputusan di tiap bulannya.

Tipe laporan dapat dikelompokkan berdasarkan waktu tertentu, yaitu [12]:

- Laporan Reguler/ Periodik

Laporan yang disiapkan sesuai jadwal tertentu untuk mendukung pengambilan keputusan. Contoh: laporan penjualan perminggu, laporan stok barang per periode.

- Laporan Khusus/ Pengecualian

Laporan yang disiapkan bila sesuatu yang luar biasa terjadi. Laporan khusus memiliki ciri kekinian yang biasanya tidak ada dalam laporan periodik.

- Laporan Tidak Terjadwal

Laporan yang dicetak berdasarkan kebutuhan, tidak ada jadwal tetap. Contohnya : laporan penjualan tertinggi.

- Laporan Analisis Khusus

Laporan yang sudah dibuatkan pattern atau cara analisanya. Biasanya digunakan untuk mengambil keputusan untuk hal-hal yang sangat penting/khusus. 
- Laporan process inquiry

Laporan yang mencetak data transaksi yang sudah terjadi.

\section{Metode Pengembangan Sistem}

Dalam merancang sebuah aplikasi atau sistem, diperlukan metode-metode atau langkah-langkah dalam pembangunan atau pengembangan sistem. Dalam penelitian ini, penulis melakukan pengembangan sistem dengan metode waterfall. Metode waterfall merupakan metode pengembangan perangkat lunak yang secara umum dilakukan oleh para peneliti sistem, dengan melalui beberapa tahapan penelitian, yaitu:

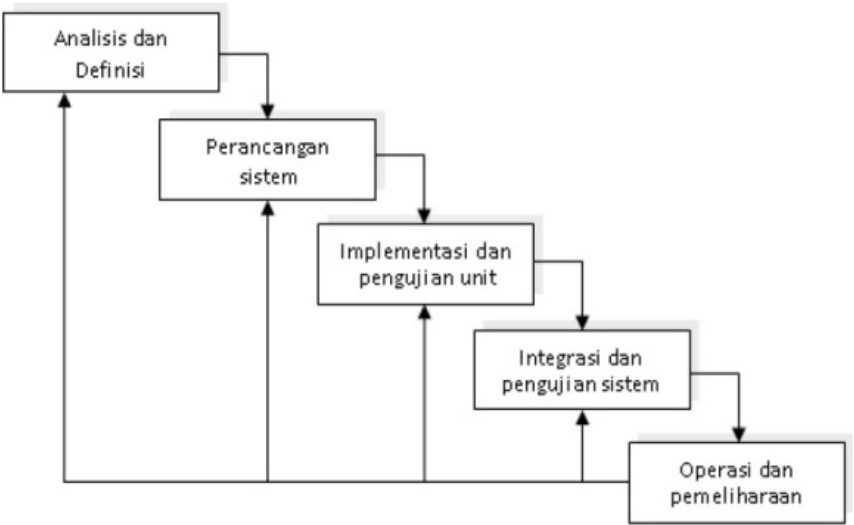

Gambar 1. Metode Pengembangan Sistem dengan Metode Waterfall (http://buzzle.com)

- Analisis dan Definisi

Tahap ini merupakan tahap dalam mencari informasi sebanyak-banyaknya mengenai sistem yang diteliti dengan melakukan metode-metode pengumpulan data sehingga ditemukan kelebihan dan kekurangan sistem serta user requirement. Selain itu, tahap ini juga dilakukan untuk mencari pemecah masalah dan menganalisa bagaimana sistem akan dibangun untuk memecahkan masalah pada sistem sebelumnya.

\section{- Perancangan Sistem}

Tahap ini merupakan tahapan perancangan sistem yang didalamnya dilakukan pemodelan sistem dengan UML, representasi interface dan coding menggunakan bahasa pemrograman C\#. 
- Implementasi dan Pengujian Unit

Tahap ini merupakan tahapan dalam pengimplementasian sistem yang sudah dirancang dan dilakukan pengujian secara unit, agar dapat mengetahui kesalahan-kesalahan yang terdapat dalam sistem dan segera dilakukan perbaikan.

- Integrasi dan Pengujian Sistem

Tahap ini merupakan tahap pengujian sistem secara keseluruhan.

- Operasi dan Pemeliharaan

Tahap ini merupakan tahapan penggunaan sistem oleh user yang didalamnya harus ada pemeliharaan sistem untuk menjaga proses operasional sistem dan memungkinkan untuk dilakukan pengembangan sistem di kemudian hari.

\section{Visualisasi Rancangan Sistem}

Dalam men-visualisasikan rancangan sistem, penulis menggunakan Unified Modelling Language(UML) sebagai tools yang digunakan dalam merancang sistem.

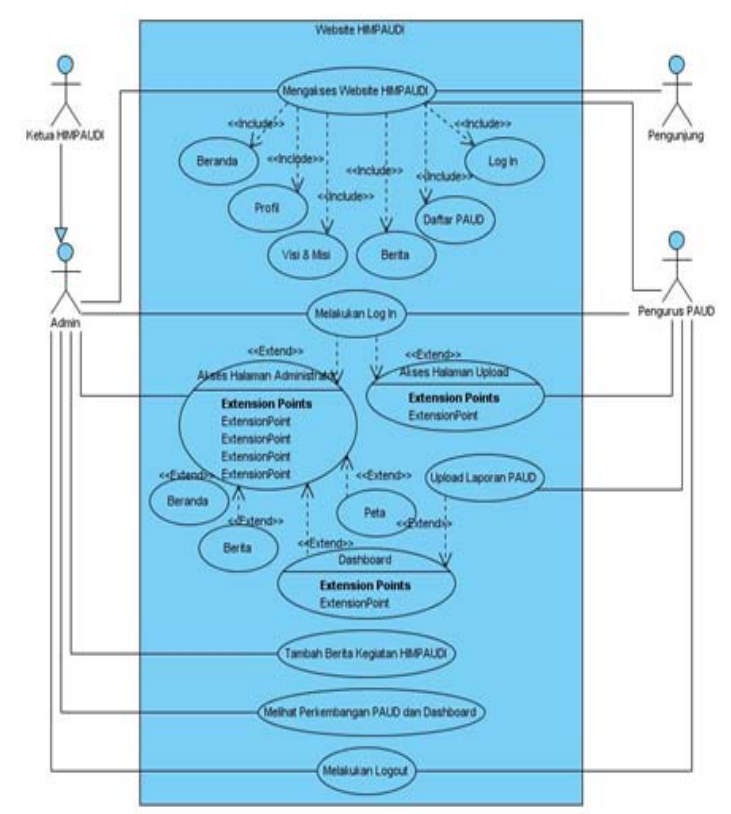

Gambar 2. Use case diagram sistem usulan HIMPAUDI Kota Tangerang 
Diagram use case merupakan diagram yang bersifat statis yang memperlihatkan himpunan use case dan aktor-aktor (suatu jenis khusus dari kelas). Diagram ini memiliki 2 fungsi, yaitu mendefinisikan fitur apa yang arus disediakan oleh sistem dan menyatakan sifat sistem dari sudut pandang user.

Diagram ini menunjukkan adanya sebuah sistem, yaitu website HIMPAUDI, yang didalamnya terdapat 4 actor yaitu, Admin, Ketua HIMPAUDI, Pengurus PAUD dan Pengunjung. Terdapat sebuah generalisasi, dan 8 use case. Terdapat 7 extend dan 6 include.

Selain use case diagram, penulis juga menggunakan activity dan state machine diagram untuk men-visualisasikan rancangan sistem usulan HIMPAUDI ini.

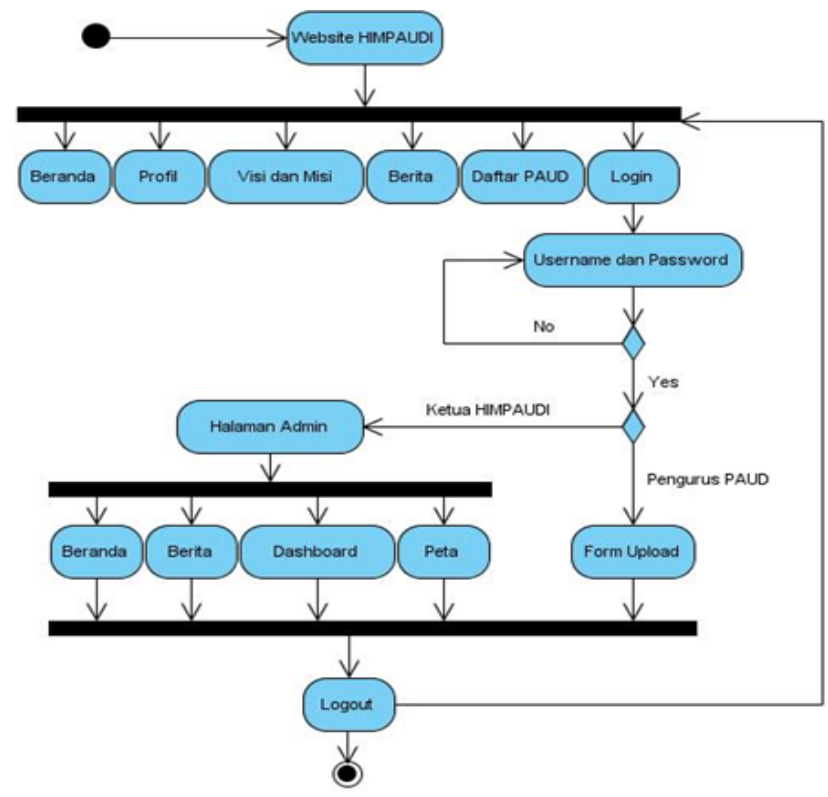

\section{Gambar 3. Activity diagram sistem usulan HIMPAUDI Kota Tangerang}

Activity diagram merupakan diagram yang bersifat dinamis. Activity diagram adalah tipe khusus dari diagram state yang memperlihatkan aliran dari suatu aktifitas ke aktifitas lainnya dalam suatu sistem dan berfungsi untuk menganalisa proses. Sedangkan state machine diagram adalah diagram yang juga bersifat dinamis. Diagram ini memperlihatkan state pada sistem; memuat state, transisi, event, serta aktifitas. 


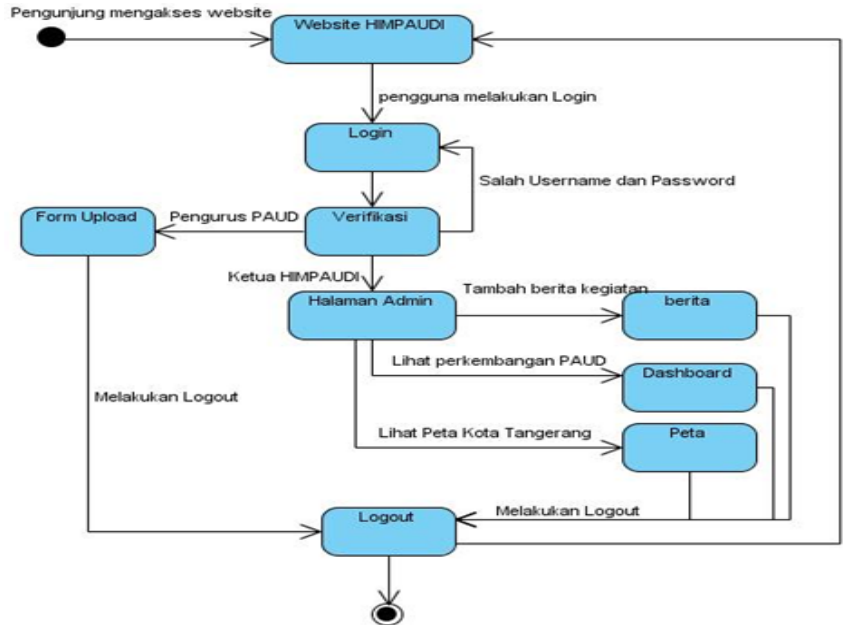

Gambar 4. State Machine diagram sistem usulan HIMPAUDI Kota Tangerang

\section{IMPLEMENTASI}

Sebagai perwujudan rancangan sistem pada penelitian diatas, maka dibuatlah sebuah sistem informasi berbasis web pada HIMPAUDI Kota Tangerang, yang dapat ditampilkan pada tampilan seperti dibawah ini:

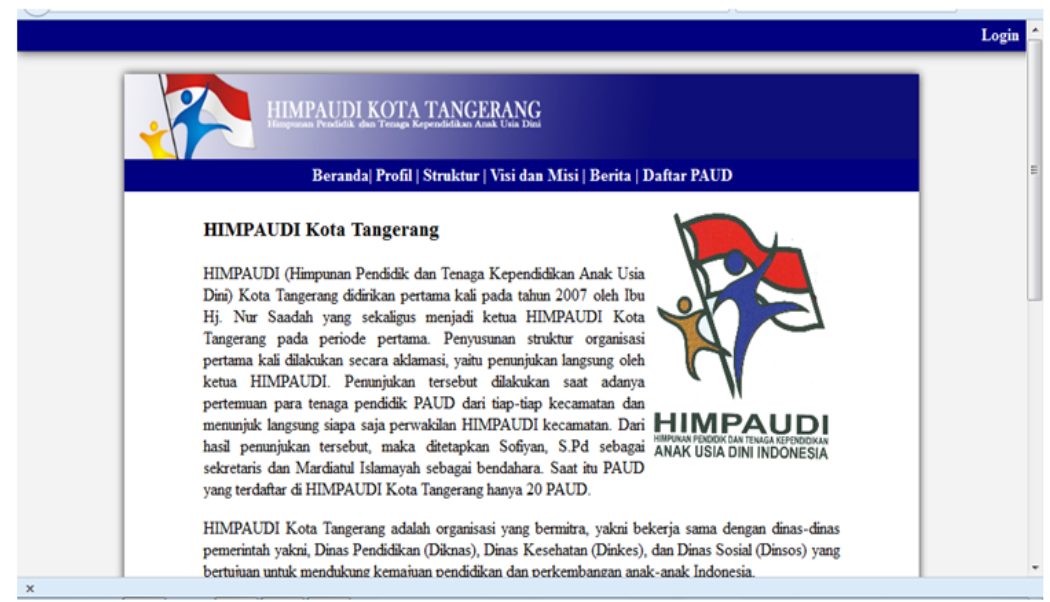

Gambar 5. Tampilan website HIMPAUDI Kota Tangerang 
Seluruh pengunjung dapat membuka website HIMPAUDI Kota Tangerang melalui browser dan harus terhubung dengan internet.

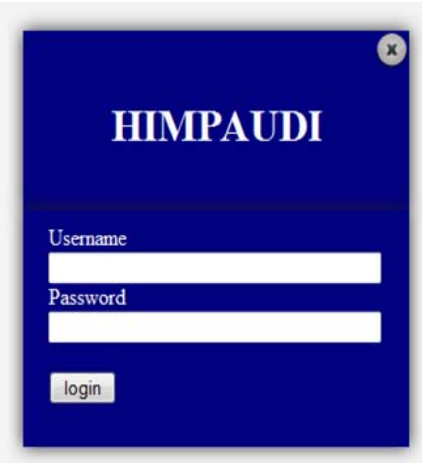

\section{Gambar 6. Form login pada website HIMPAUDI Kota Tangerang}

Setelah membuka website HIMPAUDI Kota Tangerang, Ketua HIMPAUDI dan Pengurus PAUD dapat melakukan login dengan username dan password yang sudah diberikan sebelumnya untuk masing-masing PAUD. Untuk username dan password yang sudah diprogram untuk autentifikasi Ketua HIMPAUDI, akan masuk ke halaman admin, tetapi jika username dan password dengan autentifikasi pengurus PAUD, akan masuk ke halaman upload laporan. Pada halaman upload laporan, user/pengurus PAUD dapat meng-upload laporan dalam bentuk file excel, dan kemudian langsung melakukan logout.

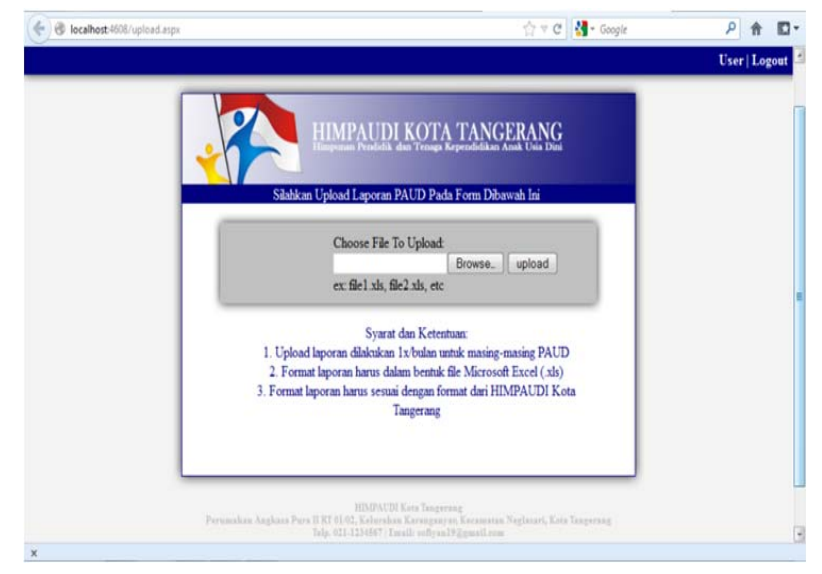

Gambar 7. Form upload laporan pada website HIMPAUDI Kota Tangerang 
Laporan PAUD yang sudah ter-upload, akan diolah oleh sistem dan dapat secara otomatis menampilkan grafik rekapitulasi dari laporan-laporan yang sudah ter-upload sebelumnya. Grafik dapat menampilkan berbagai parameter yang ingin diketahui oleh Ketua HIMPAUDI, yaitu berdasarkan perbandingan jumlah murid laki-laki dan perempuan di tiap kecamatan, perbandingan jumlah guru, perbandiangan berdasarkan umur, tahun, jenis kelamin, kelompok belajar, dan sebagainya.

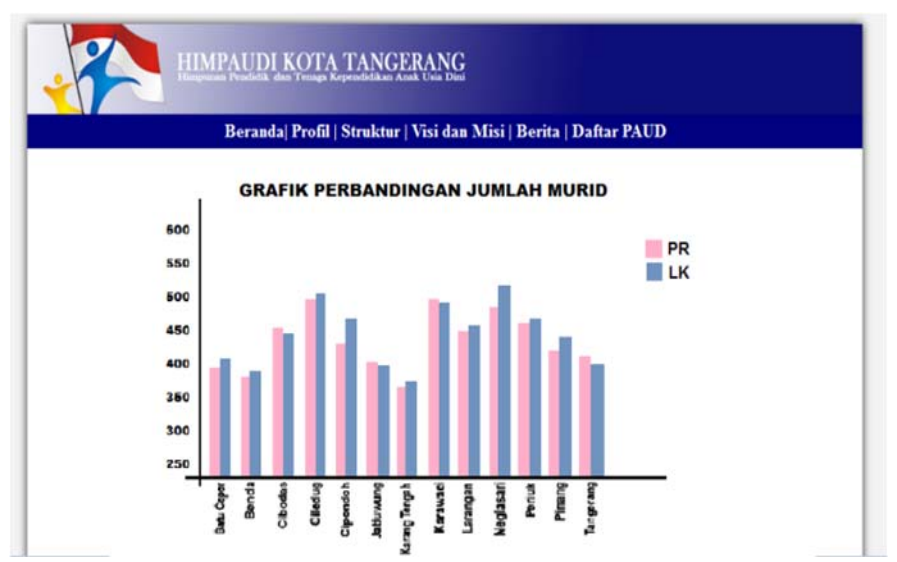

Gambar 8. Tampilan grafik perbandingan jumlah murid laki-laki dan perempuan berdasarkan kecamatan

\section{KESIMPULAN}

Kesimpulan berdasarkan rumusan masalah pada penelitian ini adalah: 1.Sistem laporan PAUD kepada HIMPAUDI saat ini masih menggunakan sistem manual yang dapat menimbulkan masalah seperti keterlambatan laporan, laporan yang hilang, bahkan rusak, perekapitulasian laporan yang tidak tepat waktu dan sulit dilakukan seorang diri oleh Ketua Himpaudi, serta masalah pengarsipan dan penyimpanan berkas laporan dengan media kertas yang menumpuk dan penuh.

2.Karena masalah-masalah tersebut, makan HIMPAUDI membutuhkan sebuah sistem yang dapat menangani maaslah tersebut dengan baik. Solusinya adalah dengan membuat sebuah sistem berbasis komputer. Karena selain penyimpanan data dan berkas secara rapi, juga mudah digunakan dam efektif.

3.Sistem berbasis komputer yang tepat diaplikasikan pada HIMPAUDI adalah sistem informasi berbasis website, karena dapat diakses dimana saja dan kapan saja dengan mudah. Dan dapat menanggulangi masalah laporan yang terjadi pada HIMPAUDI. Keterlambatan laporan yang harus diserahkan secara rutin 
perbulan oleh PAUD, dapat ditangani karena sistem berbasis website dapat diakses dimanapun di seluruh kota Tangerang sesuai lokasi penyebaran PAUD. Proses rekapitulasi dapat diproses secara baik dan tidak memerlukan waktu lama, serta meringankan kinerja HIMPAUDI. Masalah penyimpanan berkas data laporan pun menjadi baik, karena data disimpan dalam sebuah database yang aman dan tidak memerlukan banyak ruang penyimpanan.

4.Fitur yang terdapat pada aplikasi ini memang difokuskan untuk sistem pengupload-an laporan PAUD, dan tentu saja hal ini sangat meringankan kerja HIMPAUDI dan PAUD karena HIMPAUDI Kecamatan tidak perlu mendatangi PAUD satu per satu di kecamatan yang manaunginya. Pengurus PAUD hanya perlu mengakses internet, membuka website HIMPAUDI, melakukan login dan upload.

5.Untuk merealisasikan rekapitulasi laporan secara otomatis, penulis menambahkan fitur dari teknologi business intelligence, yaitu sebagai teknologi yang dapat digunakan untuk men-visualisasikan data-data tabular yang sulit dilihat dan dimengerti, dibuat secara modular berdasarkan table-tabel parameter dan ditampilkan dalam bentuk grafik. Tentu saja tampilan dalam bentuk grafik ini akan lebih mudah dimengerti oleh Ketua HIMPAUDI. Dengan begitu, Ketua HIMPAUDI dapat menganalisa dinamika perkembangan PAUD di Kota Tangerang dengan baik, serta dapat mengambil keputusan secara efektif dan efisien.

\section{DAFTAR PUSTAKA}

[1] Henderi, Rahardja, U, dkk. Dashboarding Information System for the Education Sector: Application and Methodologies. Jurnal CCIT No.5 Vol.1, September 2011.

[2] Tan, B, Foo, S, dkk. Web Information Monitoring for Competitive Intelligence. Cybernetics and System: An International Journal Vol.33, November 2010.

[3] Kusuma, Tubagus Ahmad Harja. 2012. Dashboard Monitoring Sistem Transaksi Penjualan MKIOS dalam Mendukung Sistem Klasifikasi Reward pada PT. Sastra Indah Megahmas. Skripsi:STMIK Raharja.

[4] Raishinghani, Mahesh S.,Nugent, John H. An Automated Executive and Managerial Performance Monitoring, Measurement and Reporting System. Journal of Electronic Commerce Research, Vol. 2, No. 1, 2001.

[5] Hartati, Sudi. 2009. Perancangan Sistem Penyajian Laporan Realisasi Anggaran pada Badan Pusat Statistik Kota Tangerang. STMIK Raharja. 
[6] Sauter, Vicki L. 2010. Decision Support Systems For Business Intelligence 2nd ed. Wiley: Indianapolis, Canada.

[7]AN. 2013. What Is Intelligence? Introduction. Diakses pada 13 April 2013 dari : http://intellit.muskingum.edu/whatis_folder/whatisintelintro.html

[8] Simarmata, Janner. 2010. Rekayasa Web. Yogyakarta: Andi.

[9] Rahardja U.,Augury ER, dan Asep S. 2009. Siapa Saja Bisa Membuat Website dengan CSS dan HTML. Yogyakarta: Andi.

[10] Hamdriani, VD. 2012. Analisa Penerapan Dashboard Reporting Sistem pada PLTU Lontar. Kuliah Kerja Praktek: STMIK Raharja.

[11] Kalahasthi,R and Benson Hilbert. A Short Communication on-How A Leading Power Distribution Company Effectively Tracks Business Areas Like Safety, Finance And Operation For Region And Business Wise For Evaluating Their KPI’S-Using Business Objects XCelcius Dashboards. Business Intelligence Journal - July, 2011 Vol.4 No.2.

[12]Indrayani,E dan Humdiana. 2009. Sistem Informasi Manajemen Mempersiapkan Pekerja Berbasis Pengetahuan Dalam Mengelola Sistem Informasi. Jakarta: Mitra Wacana Media. 